\title{
An improved chromogenic substrate endotoxin assay for clinical use
}

\author{
RI HARRIS, PCW STONE, J STUART \\ From the Department of Haematology, The Medical School, University of Birmingham, Birmingham \\ B15 2TJ
}

SUMMARY An improved quantitative assay for endotoxin in plasma was developed after evaluating three different chromogenic substrates and seven methods for removal of plasma inhibitors. Optimal storage conditions for plasma samples prior to assay were also determined. Using chromogenic substrate S2423 with plasma diluted $1 / 10$ in water and heated to $75^{\circ} \mathrm{C}$ for 5 min to remove inhibitors, a within-batch coefficient of variation of $4 \%$ was obtained at levels of endotoxin likely to be encountered clinically. The limit of assay sensitivity was $<10 \mathrm{pg} / \mathrm{ml}$. This assay provides a sensitive quantitative test for single episodes of endotoxaemia in individual patients but variable activation of the Limulus proenzyme by endotoxin from different bacterial strains limits quantitative comparisons between patients.

The observation that lysates of haemolymph amoebocytes from the horseshoe crab (Limulus polyphemus) gelate on exposure to minute amounts of endotoxin (bacterial lipopolysaccharide) ${ }^{1}$ generated considerable interest in the development of an endotoxin assay for clinical use. The biological activity of the endotoxin molecule resides in its lipid-A region which reacts with Limulus amoebocyte lysate (LAL) in two stages: a proenzyme present in the lysate is first activated by endotoxin and the activated proenzyme then cleaves peptide bonds in a coagulant protein causing visible gelation. ${ }^{2}$ Assays based on the gelation reaction are, however, relatively insensitive and studies of the incidence of endotoxaemia in liver failure, for example, have given conflicting results. ${ }^{3-5}$

An increase in assay sensitivity from the nanogram to the picogram range can, however, be achieved by using a chromogenic substrate to bypass the gelation reaction and thus measure the activated proenzyme directly. ${ }^{6}$ Activated Limulus proenzyme cleaves chromogenic substrates having the terminal configuration -GLY-ARG-PNA and liberates p-nitroanaline which can be read spectrophotometrically at $405 \mathrm{~nm}$. Although the chromogenic assay works well for the detection of endotoxin in water, measurements in plasma present difficulties because of poorly defined interfering proteins. ${ }^{78}$ These include $\alpha_{1}$-globulin and $\alpha_{1}$-lipoprotein esterases which degrade lipid $\mathrm{A} ;{ }^{7}$ IgM and IgG antibodies directed against lipid $\mathbf{A}$ and against the polysaccharide $O$ and $R$ antigens; ${ }^{9}$ and protease inhibitors such as $\alpha_{1}$-antitrypsin, $\alpha_{2}$-macroglobulin and antithrombin III. ${ }^{10}$ Furthermore the chromogenic substrate may be activated non-specifically by endogenous plasma amidases such as thrombin and plasmin. ${ }^{10}$ Methods used to treat plasma in an attempt to overcome these difficulties have included chloroform extraction, ${ }^{8}$ alkalinisation, ${ }^{11}$ perchloric acid, ${ }^{12} \mathrm{pH}$ shift, ${ }^{13}$ and various combinations of dilution and heating. ${ }^{14} 15$

In order to define optimal assay conditions for clinical use we have compared different methods for the removal of plasma inhibitors and have investigated the stability of endotoxin in blood and plasma under different storage conditions. The sensitivity and precision of the chromogenic substrate assay have also been determined and comparative studies made using endotoxin derived from different strains of bacteria.

\section{Material and methods}

Sterile, pyrogen-free water; new, endotoxin-free glass tubes with plastic screw caps (Mallinckrodt Inc, St Louis, Missouri); and disposable plastic pipette tips (Alpha Labs, Eastleigh, Hants) were used for all assays.

Vials of lyophilised Limulus amoebocyte lysate ("Pyrogent" Mallinckrodt) were reconstituted in 
water, to about half the manufacturer's recommended strength, and used immediately. Chromogenic substrates S2222 and S2423 (Kabi Diagnostica, Stockholm) and Chromozym TH (BCL, Lewes, Sussex) were diluted in $50 \mathrm{mmol} / \mathrm{l}$ TRIS buffer ( $\mathrm{pH} 8.8$ ) to a concentration of 3.4 $\mathrm{mmol} / \mathrm{l}$. E coli endotoxin (Mallinckrodt) was used to prepare standard curves and for recovery and stability studies; the reconstituted stock solution contained $500 \mu \mathrm{g} / \mathrm{ml}$.

\section{BLOOD SAMPLE COLLECTION}

Venepuncture was performed after skin cleansing with $70 \%$ isopropanol and blood collected into heparin (25 IU/ml; Weddel Pharmaceuticals Ltd, London) in sterile plastic universals. All heparin batches were checked for endotoxin contamination before use.

\section{ASSAY PROCEDURE}

To avoid endotoxin contamination, the assay was carried out in a Class II microbiological safety cabinet (Envair Ltd, Rossendale, Lancs). Specimens were kept on melting ice during reagent addition. The stock endotoxin was diluted to $2.5 \mathrm{ng} / \mathrm{ml}$ in water, then doubling dilutions made in normal plasma to prepare standards containing from $7 \cdot 8$ $\mathrm{pg} / \mathrm{ml}$ to $250 \mathrm{pg} / \mathrm{ml}$ of endotoxin. Before assay, both test and standard samples were treated to remove plasma inhibitors. The assay was performed as shown in Table 1 . Final optical density values (OD) were calculated by subtracting both the test and reagent blank readings from the test reading.

\section{METHODS FOR THE REMOVAL OF PLASMA}

\section{INHIBITORS}

Seven methods were studied:

1 Chloroform extraction. ${ }^{8}$

2 pH shift: glacial acetic acid $(0.2 \mathrm{ml} 25 \% \mathrm{vol} / \mathrm{vol})$ was added to $1 \mathrm{ml}$ plasma to lower the $\mathrm{pH}$ to $4 \cdot 0 \pm$ $0 \cdot 1$. The $\mathrm{pH}$ was then returned to $6 \cdot 2 \pm 0.1$ by the

Table 1 Endotoxin assay procedure

\begin{tabular}{|c|c|c|c|}
\hline & Test/standard & $\begin{array}{l}\text { Test/standard } \\
\text { blank }\end{array}$ & $\begin{array}{l}\text { Reagent } \\
\text { blank }\end{array}$ \\
\hline $\begin{array}{l}\text { Test/standard sample } \\
\text { (diluted and heated) } \\
\text { Add pyrogen-free water } \\
\text { Add LAL } \\
\text { Incubate at } 37^{\circ} \mathrm{C} \text { for } \\
45 \mathrm{~min} \\
\text { Add chromogenic } \\
\text { substrate } \\
\text { After exactly } 3 \mathrm{~min} \text {, add } \\
\text { glacial acetic acid }\end{array}$ & $\begin{array}{l}\frac{0.2 \mathrm{ml}}{0.2 \mathrm{ml}} \\
0.5 \mathrm{ml} \\
0.3 \mathrm{ml}\end{array}$ & $\begin{array}{l}0.2 \mathrm{ml} \\
0.2 \mathrm{ml} \\
-\end{array}$ & $\begin{array}{l}\overline{0.2} \mathrm{ml} \\
0.2 \mathrm{ml}\end{array}$ \\
\hline
\end{tabular}

Read spectrophotometrically at $405 \mathrm{~nm}$. addition of $0.2 \mathrm{ml}$ of $2.8 \mathrm{M}$ dibasic potassium phosphate (pH 9.4). ${ }^{13}$

3 Perchloric acid $(0.2 \mathrm{ml}$ of $1.9 \% \mathrm{vol} / \mathrm{vol})$ was added to $0.1 \mathrm{ml}$ of plasma and the mixture incubated at $37^{\circ} \mathrm{C}$ for $20 \mathrm{~min}$. After centrifugation at $1500 \mathrm{~g}$ for $15 \mathrm{~min}, 0.1 \mathrm{ml}$ of $0.2 \mathrm{M} \mathrm{NaOH}$ was added to $0.1 \mathrm{ml}$ of supernatant and the mixture assayed. ${ }^{12}$

4 Dilution of plasma (1/4) in $50 \mathrm{mmol} / \mathrm{l}$ TRIS buffer $\left(\mathrm{pH} \mathrm{7.0)}\right.$ ) followed by heating at $100^{\circ} \mathrm{C}$ for 5 $\min .^{14}$

5 Dilution of plasma (1/2) in water followed by heating at $100^{\circ} \mathrm{C}$ for $12 \mathrm{~min}$ and then by centrifugation at $1500 \mathrm{~g}$ for $10 \mathrm{~min}$ to provide supernatant for assay. ${ }^{16}$

6 Dilution of plasma $(1 / 100)$ in water.

7 Dilution of plasma (1/10) in water followed by heating at $75^{\circ} \mathrm{C}$ for $5 \mathrm{~min}$.

\section{Results}

REMOVAL OF PLASMA INHIBITORS

Treatment of plasma by chloroform extraction or $\mathrm{pH}$ shift resulted in solutions too turbid for spectrophotometric assay. Addition of perchloric acid $\stackrel{\Phi}{\triangle}$ has been claimed to allow the detection of $20 \mathrm{pg} / \mathrm{ml} \overrightarrow{0}$ of endotoxin ${ }^{12}$ but we were unable to dete endotoxin at levels below $250 \mathrm{pg} / \mathrm{ml}$. The tw methods (4 and 5) employing plasma dilution and boiling allowed the assay of $0 \cdot 5-1 \mathrm{ng} / \mathrm{ml}$ endotoxin? Both dilution in water $(1 / 100)$ without heating and dilution in water $(1 / 10)$ followed by heating to $75^{\circ} \mathrm{C}$ for $5 \mathrm{~min}$, appeared equally effective for inhibitor removal but the latter method required less sample

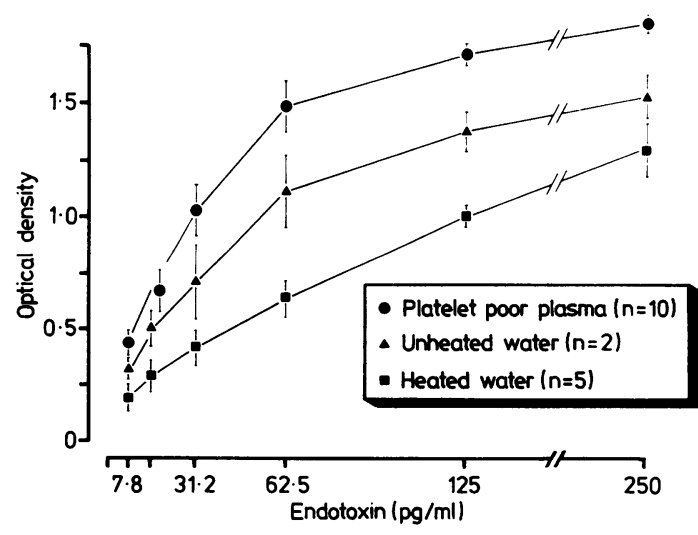

Fig. 1 Standard curves (mean and SEM) obtained for endotoxin in platelet poor plasma (diluted $1 / 10$ and heated at $75^{\circ} \mathrm{C}$ for $5 \mathrm{~min}$ ) and for endotoxin in water (diluted $1 / 10$ with and without heating). 
dilution and this increased assay sensitivity to endotoxin levels of $<10 \mathrm{pg} / \mathrm{ml}$. All further assays were therefore performed using a $1 / 10$ dilution of plasma in water followed by heating at $75^{\circ} \mathrm{C}$ for 5 min. An unexpected finding (Fig. 1) was a consistently higher optical density reading obtained with dilutions of endotoxin in plasma compared with similar dilutions in water, both with and without heating at $75^{\circ} \mathrm{C}$, suggesting that a physicochemical change may take place when endotoxin is dissolved in plasma thus enhancing reactivity.

\section{COMPARISON OF CHROMOGENIC SUBSTRATES}

Solutions $(3.4 \mathrm{mmol} / \mathrm{l})$ of the three chromogenic substrates were prepared in $50 \mathrm{mmol} / \mathrm{l}$ TRIS buffer (pH 8.8) and used to assay identical standard dilutions of endotoxin in plasma. All assays were performed in one batch using the same freshlyreconstituted vial of LAL. The results (Fig. 2) showed higher OD values with S2222 and S2423 compared with Chromozym TH and subsequent assays were therefore performed using S2423 (manufacturer's recommendation).

\section{ENDOTOXIN RECOVERY FROM PLASMA}

Platelet-rich plasma (PRP) was prepared from normal heparinised blood by centrifugation at $100 \mathrm{~g}$ for $15 \mathrm{~min}$ at $4^{\circ} \mathrm{C}$. $E$ coli endotoxin was added to the supernatant plasma at concentrations of $1 \mathrm{ng} / \mathrm{ml}$ and $50 \mathrm{pg} / \mathrm{ml}$ and the specimens stored at $4^{\circ} \mathrm{C}$. An aliquot was removed from each specimen at 30 and 90 min and centrifuged at $1300 \mathrm{~g}$ for $5 \mathrm{~min}$ at $4^{\circ} \mathrm{C}$ to produce platelet-poor plasma (PPP). Simultaneous endotoxin assays were then performed on the paired PRP and PPP specimens; virtually identical recovery (Table 2) was obtained at both 30 and $90 \mathrm{~min}$ and all further studies were therefore performed using PPP.

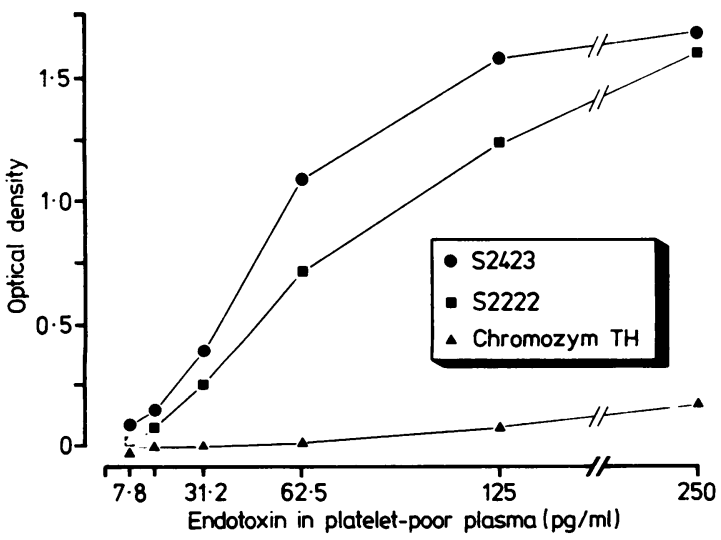

Fig. 2 Standard curves obtained using three different chromogenic substrates.
Table 2 Recovery of endotoxin from PRP and PPP, stored at $4^{\circ} \mathrm{C}$, from one healthy individual. Results expressed as percentage of the $O D$ reading obtained within 2 min of endotoxin addition

\begin{tabular}{|c|c|c|c|c|}
\hline \multirow{2}{*}{$\begin{array}{l}\text { Endotoxin } \\
\text { concentration }\end{array}$} & \multicolumn{2}{|c|}{ Recovery at $30 \mathrm{~min}$} & \multicolumn{2}{|c|}{ Recovery at $90 \mathrm{~min}$} \\
\hline & $\widehat{P R P}$ & $P P P$ & PRP & $P P P$ \\
\hline $\begin{array}{r}1 \mathrm{ng} / \mathrm{ml} \\
50 \mathrm{pg} / \mathrm{ml}\end{array}$ & $\begin{array}{l}76 \\
72\end{array}$ & $\begin{array}{l}78 \\
74\end{array}$ & $\begin{array}{l}77 \\
74\end{array}$ & $\begin{array}{l}77 \\
69\end{array}$ \\
\hline
\end{tabular}

\section{EFFECT OF STORAGE TEMPERATURE ON} ENDOTOXIN STABILITY

To determine the optimal storage conditions for clinical specimens, a known amount $(1 \mathrm{ng} / \mathrm{ml})$ of $E$ coli endotoxin was added to one normal whole blood and plasma. Aliquots were stored at 4, 22 and $37^{\circ} \mathrm{C}$ and assays performed at $0 \cdot 5,1$ and $3 \mathrm{~h}$. There was no difference (Fig. 3) between the stability of endotoxin in whole blood or PPP at any temperature. Storage at $4^{\circ} \mathrm{C}$, however, resulted in greater endotoxin recovery than at either 22 or $37^{\circ} \mathrm{C}$. An additional sample assayed after 3, 24, 48 and $72 \mathrm{~h}$ storage at $4^{\circ} \mathrm{C}$ showed a decline in endotoxin concentration to approximately $30 \%$ at $72 \mathrm{~h}$.

Further studies of the effect of storage at $4^{\circ} \mathrm{C}$ on a wider range of endotoxin concentrations $(10 \mu \mathrm{g} /$ $\mathrm{ml}-50 \mathrm{pg} / \mathrm{ml}$ ) in normal PPP, and on the endotoxin-containing plasma of two patients with Gram-negative septicaemia, were also made. Very little loss of activity occurred between 30 and 150 min storage in PPP to which endotoxin had been added in vitro; one of the two patient specimens, however, showed approximately $50 \%$ loss of activity after $150 \mathrm{~min}$.

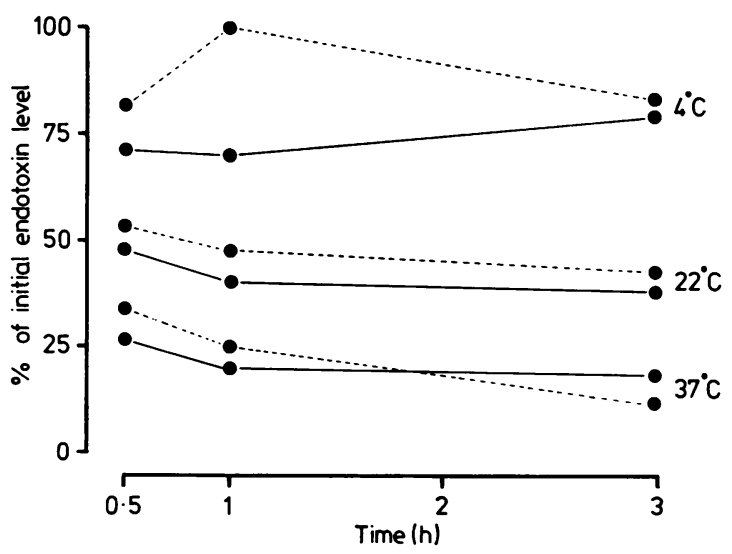

Fig. 3 Effect of temperature on endotoxin $(1 \mathrm{ng} / \mathrm{ml})$ stability in whole blood (-----) and in platelet-poor plasma $(-)$. Results expressed as percentage of initial optical density reading obtained within two minutes of endotoxin addition. 


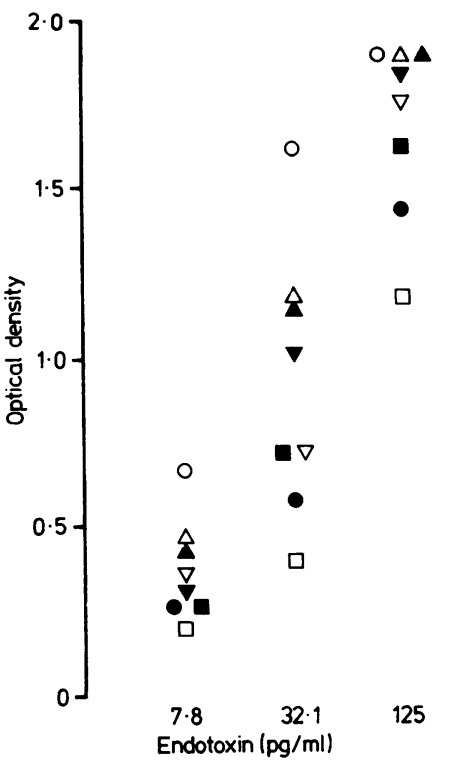

Fig. 4 Optical density readings for eight phenol extracts of endotoxin dissolved in plasma $(\mathrm{O}-E$ coli $0128: B 12, \triangle-S$ enteritidis, $\square-E$ coli $026: B 6, \nabla-E$ coli $0111: B 4, \bullet-S$ minnesota, $\triangle-E$ coli 0127:B8, $\square-S$ marcescens, $\nabla-E$ coli 055:B5).

The effect of long-term storage at $-40^{\circ} \mathrm{C}$ was investigated by assaying, at approximately fortnightly intervals, a specimen of PPP containing $100 \mathrm{pg} / \mathrm{ml}$ endotoxin which had been diluted, heated, and stored in aliquots. No loss of activity was found over a three-month period.

\section{SENSITIVITY OF ASSAY TO DIFFERENT \\ BACTERIAL ENDOTOXINS}

Phenol or trichloroacetic acid (TCA) extracts of bacterial strains (Sigma Chemical Co, Poole, Dorset) were studied. Before assay, dilutions of each endotoxin (from $7 \cdot 8-125 \mathrm{pg} / \mathrm{ml}$ ) were made in one normal plasma and in water. A wide variation in optical density readings was obtained for phenol extracts of endotoxin dissolved in plasma (Fig. 4). A similar scatter of results was obtained for both phenol and TCA extracts dissolved in water.

\section{ASSAY PRECISION}

Using chromogenic substrate $\mathbf{S 2 4 2 3}$, with specimens diluted $1 / 10$ in water and heated to $75^{\circ} \mathrm{C}$ for $5 \mathrm{~min}$ to remove plasma inhibitors, a within-batch coefficient of variation (CV) of $4 \%$ was obtained for 10 samples containing $50 \mathrm{pg} / \mathrm{ml}$ endotoxin. At the limit of sensitivity of the assay $(10 \mathrm{pg} / \mathrm{ml})$ the within batch $\mathrm{CV}$ was $17 \%$ for 10 samples and the between batch $\mathrm{CV}$ was $25 \%$ for 17 batches.

\section{Discussion}

This chromogenic substrate assay for endotoxin, compared with the LAL gelation assay, has the advantages of sensitivity (to at least $10 \mathrm{pg} / \mathrm{ml}$ ), $\stackrel{\vec{D}}{\vec{O}}$ speed, and an objective end-point. It was also reproducible (within-batch $\mathrm{CV}$ of $4 \%$ ) at levels of endotoxin likely to be found clinically. Contamination with extraneous endotoxin which may have $\stackrel{\square}{\AA}$ occurred in previous studies, ${ }^{4}$ was minimised by performing the assay in a laminar-air-flow cabinet and by the use of new, endotoxin-free tubes for each test; our attempts to decontaminate used tubes were not successful. Dilution and heating of the test plasma was found to be an effective method for 8 removing inhibitors and was 50 times more sensitive than methods involving boiling. Greater recovery of added endotoxin from normal plasma, compared with water, was a consistent finding. Lipid-A is lipophilic and has been shown to form complexes $O$ with high density lipoprotein in plasma. ${ }^{17}$ The 을 improved physical dispersion resulting from such $\vec{\sim}$ binding may enhance interaction with the LAL $\bigcirc$ proenzyme and thus cause an apparent increase in the yield from plasma.

Our studies of the recovery and stability $\left(\right.$ at $\left.4^{\circ} \mathrm{C}\right) \overrightarrow{\vec{c}}$ of endotoxin added to normal plasma and to wholg blood suggested an initial period of endotoxi degradation followed by a period of relative stabilit for $2-3 \mathrm{~h}$. Blood specimens from endotoxaemi patients are, however, already likely to have reached $\bar{\partial}$ equilibrium in vivo. Such specimens should be kept at $4^{\circ} \mathrm{C}$ and, ideally, processed within $2-3 \mathrm{~h}$ but $\stackrel{\mathbb{2}}{2}$ uncentrifuged specimens stored overnight at $4^{\circ} \mathrm{C} \overrightarrow{\overrightarrow{0}}$ may still contain detectable endotoxin. If the assay 3 cannot be performed within 2-3 h of venepuncture, the plasma should be diluted and heated; it may then be stored at $-40^{\circ} \mathrm{C}$ without significant loss of activity for at least 3 months. Although endotoxin is known to bind to platelets, we found no difference 3 in the recovery of endotoxin from PRP or PPP and used PPP because centrifugation is rapid and the specimen handling time thereby reduced.

There appear to be real differences in the degree $\frac{\text { 을 }}{7}$ of activation of the Limulus proenzyme by different $\frac{7}{0}$ endotoxins, possibly related to structural variations of the polysaccharide $\mathrm{O}$ antigen and to differences in $\widetilde{N}$ the degree of physical dispersion in solution. N Although variations in the extraction procedure $N$ might be expected to cause some loss of uniformity ${ }^{\omega}$ when apparently similar amounts of endotoxin from different sources are tested, such variations are $\stackrel{\varrho}{\simeq}$ unlikely to account for differences of the magnitude $\stackrel{\Phi}{\mathscr{D}}$ found in our experiments and by others. ${ }^{18}$ This $\stackrel{?}{?}$ finding has implications for the measurement of ${ }^{-}$ endotoxin in clinical studies since considerable $\mathbb{D}$ 
quantitative error may be introduced if the assay is standardised using an endotoxin preparation derived from an organism different from that causing a clinical episode of endotoxaemia. For this reason, endotoxin assays should not be expressed in terms of concentration unless both the test and the standard endotoxin are from an identical source. The alternative to absolute units of endotoxin concentration is to use arbitrary units of optical density, but again this does not allow inter-patient comparison unless the infecting organisms have been isolated and shown to be of identical serotype. Species differences are therefore likely to limit the application of this improved assay for endotoxin to the serial, quantitative investigation of single episodes of endotoxaemia in individual patients. A study of the incidence of endotoxaemia in immunosuppressed patients is now in progress.

We are indebted to the Leukaemia Research Fund for financial support and to Mrs JL Roper for technical assistance.

\section{References}

' Bang F. A bacterial disease of Limulus polyphemus. Bulletin of the Johns Hopkins Hospital 1956;98:325-51.

2 Young NS, Levin J, Prendergast RA. An invertebrate coagulation system activated by endotoxin: evidence for enzymatic mediation. J Clin Invest 1972;51:1790-7.

${ }^{3}$ Prytz H. Holst-Christensen J, Korner B, Liehr H. Portal venous and systemic endotoxaemia in patients without liver disease and systemic endotoxaemia in patients with cirrhosis. Scand $J$ Gastroenterol 1976;11:857-63.

${ }^{4}$ Fulenwider JT, Sibley C, Stein SF, et al. Endotoxemia of cirrhosis: an observation not substantiated. Gastroenterology 1980;78:1001-4.

s Wilkinson SP, Arroyo V, Gazzard BG, et al. Relation of renal impairment and haemorrhagic diathesis to endotoxaemia in fulminant hepatic failure. Lancet $1974 ; \mathrm{i}: 521-4$.

- Iwanaga S, Morita T, Harada T, et al. Chromogenic substrates for horseshoe crab clotting enzyme. Haemostasis 1978;7:183-8.

${ }^{7}$ Scarnes RC. The inactivation of endotoxin after interaction with certain proteins of normal serum. Ann NY Acad Sci 1966;133:644-62.

- Levin J, Tomasulo PA, Oser RS. Detection of endotoxin in human blood and demonstration of an inhibitor. J Lab Clin Med 1970;75:903-11.

'Wardle N. Bacteraemic and endotoxic shock. Br J Hosp Med 1979;21:223-31.

${ }^{10}$ Webster CJ. Principles of a quantitative assay for bacterial endotoxins in blood that uses Limulus lysate and a chromogenic substrate. J Clin Microbiol 1980;12:644-50.

"Takagi K, Moriya A, Tamura H, et al. Quantitative measurement of endotoxin in human blood using synthetic chromogenic substrate for horseshoe crab clotting enzyme: a comparison of methods of blood sampling and treatment. Thromb Res 1981;23:51-7.

12 Obayashi T, Kawai T, Tamura H, Nakahara C. New limulus amoebocyte lysate test for endotoxaemia. Lancet 1982;i:289.

${ }^{13}$ Reinhold RB, Fine J. A technique for quantitative measurement of endotoxin in human plasma. Proc Soc Exp Biol Med 1971;137:334-40.

14 Thomas LLM, Sturk A, Kahle LH, ten Cate JW. Quantitative endotoxin determination in blood with a chromogenic substrate. Clin Chim Acta 1981;116:63-8.

is Goto H, Nakamura S. Dry-up method as a revised Limulus test with a new technique for gelation inhibitor removing. Jpn $J$ Exp Med 1979;49:19-25.

16 Jacob AI, Goldberg BS, Bloom N, et al. Endotoxin and bacteria in portal blood. Gastroenterology 1977;72:1268-70.

${ }^{17}$ Ulevitch RJ, Johnston AR, Weinstein DB. New function for high density lipoproteins. J Clin Invest 1981;67:827-37.

${ }^{18}$ Scully MF, Newman YM, Clark SE, Kakkar VV. Evaluation of a chromogenic method for endotoxin measurement. Thromb Res 1980;20:263-70.

Requests for reprints to: Professor J Stuart, Department of Haematology, The Medical School, University of Birmingham, Birmingham B15 2TJ, England. 